\title{
TUBUH PEREMPUAN DALAM BUDAYA KONSUMEN: ANTARA KESENANGAN DIRI, STATUS SOSIAL, DAN NILAI PATRIARKI
}

\author{
Ida Rosida ${ }^{12}$
}

\begin{abstract}
This article discusses the J akarta urban women body in Indonesian consumer culture as reflected in Miss Jinjing Belanja Sampai Mati (2008) by Amelia Masniari. Within consumer culture, consuming commodities is seen as a natural. However, it is the impact of the power (dominant ideologies) that present in that culture. The primary objective of this paper is to explore how the Jakarta urban woman body is constructed within Indonesia's consumer culture in which portrayed in Miss J injing Belanja Sampai Mati (2008) through the character of Amelia Masniari. This is a qualitative research with cultural studies approach. The concept of Mike Featherstone about the body in consumer culture is used to analyze the text. The results show that the J akarta urban woman body as reflected through Amelia's character is constructed by capitalis $m$, consumerism and patriarchal ideology. The emergence of these three ideologies are seen through contradictions in the text such as the contradiction between values of self-pleasure, social status as well as patriarchal values. In conclusion, the J akarta urban woman body (Amelia) in Indonesian consumer culture as reflected in Miss Jinjing Belanja Sampai Mati (2008) is site of ideological contestation; capitalism, consumerism and patriarchal ideology. The presence of these ideologies are not mutually tearing down but mutually reinforcing one another and in the end there is coherence between each ideology.
\end{abstract}

Keywords: Woman body construction, urban life style, consumer culture, ideology

\section{Abstrak}

Artikel ini membahas tubuh perempuan urban Jakarta dalam budaya konsumen Indonesia seperti tercermin dalam Miss J injing Belanja Sampai Mati (2008) karya Amelia Masniari. Dalam budaya konsumen, mengonsumsi seolah menjadi hal yang alami. Namun, sesungguhnya hal tersebut merupakan dampak dari adanya kekuasaan (ideologi-ideologi dominan) yang hadir dalam sebuah budaya. Tujuan utama penelitian ini adalah untuk menunjukkan bagaimana tubuh perempuan urban J akarta dikonstruksi oleh budaya konsumen Indonesia seperti tercermin dalam Miss J injing Belanja Sampai Mati (2008) melalui tuturan Amelia Masniari di dalam teks. Perilaku konsumsi Amelia di dalam teks tidak bisa dilepaskan dari kekuasaan ideologi yang pada akhirnya turut menentukan gaya hidupnya sebagai perempuan urban Jakarta yang konsumtif. Penelitian ini adalah penelitian kualitatif dengan pendekatan Cultural Studies. Selanjutnya, konsep Mike Featherstone mengenai tubuh dalam budaya konsumen digunakan untuk menganalisis teks. Hasil penelitian menunjukkan bahwa tubuh perempuan urban Jakarta yang tercermin melalui tokoh Amelia dikonstruksi oleh ideologi kapitalisme, konsumerisme dan ideologi patriarki. Munculnya ketiga

\footnotetext{
${ }^{1}$ Dosen Program Studi Sastra Inggris Fakultas Adab dan Humaniora, UIN Syarif Hidayatullah, Jakarta

${ }^{2}$ Korespondensi Penulis, email: idarosida@uinjkt.ac.id

DOI: 10.25077/jantro.v20.n1.p85-101.2018

JANTRO ISSN: 2355-5963 (Online)

under Lisensi Creative Commons Atribusi-BerbagiSerupa 4.0 Internasional
} 
ideologi ini terlihat melalui kontradiksi-kontradiksi dalam teks seperti kontradiksi antara nilai-nilai kesenangan diri, status sosial juga nilai-nilai patriarki. Dari analisis tersebut dapat disimpulkan bahwa tubuh perempuan urban Jakarta (Amelia) dalam budaya konsumen Indonesia seperti tercermin dalam Miss J injing Belanja Sampai Mati (2008), merupakan situs pertarungan ideologi yaitu ideologi kapitalisme, konsumerisme dan ideologi patriarki. Ketiga ideologi ini saling mengukuhkan satu sama lain dan tidak ada satu ideologi pun yang runtuh, sehingga pada akhirnya terjadi koherensi antar masing-masing ideologi.

Kata Kunci: Konstruksi tubuh perempuan, gaya hidup urban, budaya konsumen, ideologi

\section{A. PENDAHULUAN}

$\mathrm{K}$ ehidupan perempuan urban khusus nya di Jakarta tak bisa dilepaskan dari urusan konsumsi. Maraknya fasilitasfasilitas perkotaan seperti pusat-pusat perbelanjaan, restoran, kafe, salon dan klinik kecantikan turut menunjang perilaku masyarakat urban yang gemar mengon sumsi. Begitu pula halnya dengan akses terhadap informasi yang dapat diperoleh dengan mudah melalui media cetak maupun elektronik berupa internet, televisi, dan berbagai teknologi lainnya. Tak hanya itu, maraknya on line shopping semakin memanjakan mereka untuk membeli segala komoditas yang diinginkan. Keberadaan fasilitas-fasilitas tersebut mempermudah perempuan urban dalam menentukan gaya hidupnya dan menjadi konsumtif. Su pangkat, dkk (2005) mengatakan bahwa salah satu ciri yang melekat dalam masyarakat urban adalah terciptanya gaya hidup konsumtif. Maraknya konsumsi komoditas tiada batas ini menandakan bahwa budaya konsumen di Indonesia semakin berkembang.

Budaya konsumen adalah sebuah budaya dimana sebuah komoditas dibuat sedemikian rupa sehingga memunculkan impian-impian yang sengaja dikonstruksi secara sosial, utamanya oleh sistem kapitalis. Misal, iklan dalam media mampu menyulap komoditas tertentu dan memberi kan konsep tubuh yang ideal versi kapitalis. Featherstone (1982) mengungkapkan "with in consumer culture, advertisements, the popular press, television and motion pictures, provide a proliferation of stylised images of the body. Senada dengan Lurry (2013) yang menyebutkan bahwa salah satu penyebab berkembangnya budaya konsu men adalah terjadinya manipulasi ruang dan waktu melalui media periklanan. Media ini, kemudian, mengarahkan masyarakat untuk meraih kebutuhan akan eksistensi diri (Noerhadi, 2014), dan hal yang dilakukan selanjutnya adalah mengonsumi komoditas yang dapat mengahadirkan citra yang yang diinginkan.

Menurut Kozinet (dalam Arnould dan Thompson, 2005), istilah budaya konsumen juga mengkonseptualisasikan sistem yang saling berhubungan antara gambar, teks, dan objek komersil yang digunakan oleh kelompok-kelompok tertentu melalui kon struksi praktek, identitas, dan makna. Artinya, segala praktek budaya yang dilaku kan masyarakat konsumen tak lepas dari sebuah sistem yang merupakan sebuah konstruksi sosial terhadap segala bentuk komoditas. Menurut Arnould dan Thompson (2005) makna ini diwujudkan dan dinego siasikan oleh konsumen dalam peran dan hubungannya dalam situasi sosial tertentu.

Dalam budaya konsumen, tubuh meme gang peranan penting karena melalui tubuhlah seseorang baik laki-laki atau perempuan dapat mengkonstruksi identitas nya berdasarkan apa yang dikonsumsinya. Jagger (2000) mengatakan "anyone can be anyone as long as they have the means to participate in consumption", sesorang bisa menjadi siapapun selama la memiliki modal untuk membeli segala yang dikonsumsinya. Tindakan mengonsumsi kemudian bisa menjadi alat bagi seseorang untuk menego siasikan dan mengartikulasikan identitasnya.

DOI: 10.25077/jantro.v20.n1.p85-101.2018

JANTRO ISSN: 2355-5963 (Online)

under Lisensi Creative Commons Atribusi-BerbagiSerupa 4.0 Internasional 
Budaya konsumen menitikberatkan pada citra tubuh, tubuh langsing, tubuh sexy, dan tubuh ideal. Tubuh, kemudian bukanlah tubuh yang sifatnya pribadi (private) tapi secara sosial, tubuh menjadi public political issues (Shilling, 2016). Anthony Synnott, dalam bukunya Tubuh Sosial, Simbolisme, Diri dan Masyarakat (2007) menuturkan bahwa tubuh tak bisa lepas dari konstelasi sosial, politik, ekonomi dan budaya yang melingkupinya. Hal ini menegaskan bahwa kehadiran tubuh dalam sebuah masyarakat tak lepas dari aspek sosial, politik, ekonomi dan budaya sehingga tubuh menjadi tubuh sosial dan memiliki nilai politis. Dengan demikian, jelas bahwa dalam budaya konsumen, tubuh tidak dilihat sebagai tubuh biologis saja tetapi sebagai tubuh sosial yang sarat dengan nilai-nilai budaya dimana tubuh tersebut hadir. Dalam budaya konsumen ini pun, tubuh bisa dikonstruksi oleh berbagai macam ideologi (Mochtar, 2008).

Salah satu buku non fiksi gaya hidup dengan judul Miss Jinjing Belanja Sampai Mati (2008) karya Amelia Masniari memperlihatkan bagaimana tubuh khusus nya tubuh seorang perempuan memiliki makna penting dalam sandaran budaya konsumen. Tubuh tidak hanya dilihat berdasarkan wujud fisiknya saja melainkan dilihat dari apa yang melekat pada tubuh tersebut. Buku ini memaparkan pengalaman pribadi Amelia, seorang perempuan asal Jambi yang berdomisili di Jakarta yang dikenal dengan gaya hidup konsumtif. Didalamnya, buku ini memaparkan gaya hidup perempuan yang praksis dari dirinya dan yang dia cerap dari diri perempuan lain. Adapun isi dari buku tersebut yaitu berupa tips-tips berbelanja, curhat, dan filosofis mengenai sisi perempuan yang tidak bisa dilepaskan dari kehidupan laki-laki. Buku ini telah dibaca oleh 10.000 orang dan $90 \%$ pembacanya adalah perempuan (Masniari, 2011, Komunitas Belanja Sampai Mati, http://belanja-sampai-mati.blogspot.com/ 2011/10/komunitas-miss-jinjing.html, diakses tanggal 30 April 2018). Perilaku konsumsi dan gaya hidup perempuan urban Jakarta seperti tercermin dalam Miss Jinjing Belanja Sampai Mati (2008), merupakan sebuah fenomena mengenai perempuan urban
Jakarta yang hidup dalam lingkaran budaya konsumen Indonesia.

Sebagai sebuah fenomena budaya, tindakan mengonsumsi bagi perempuan urban Jakarta seperti Amelia merupakan hal yang tak terpisahkan dalam kesehariannya. la hidup di kota metropolitan dan biasa menikmati berbagai fasilitas yang tersedia seperti pusat-pusat perbelanjaan, salonsalon kecantikan, restoran, juga cafe-cafe yang sengaja diciptakan untuk menunjang aktifitas masyarakat perkotaan. Mengonsum si telah menjadi salah satu rutinitas dalam keseharian perempuan urban saat ini termasuk Amelia, dan pada akhirnya mengonsumsi merupakan cara terbaik yang dipilih perempuan untuk mengonstruksi tubuhnya sesuai dengan kriteria-kriteria yang diinginkannya.

Ada pun permasalahan yang muncul dalam Miss Jinjing Belanja Sampai Mati (2008) yaitu mengenai sosok Amelia sebagai cermin perempuan urban Jakarta yang mengonstruksi tubuhnya melalui paparannya dalam mengonsumsi berbagai komoditas sebagai akibat adanya berbagai macam ideologi yang ada dalam budaya konsumen Indonesia. Dalam budaya konsu men, tubuh tidaklah dilihat sebagai tubuh yang tanpa nilai karena ia dipengaruhi oleh sosial budaya tempat dimana tubuh tersebut hadir, sehingga tindakan mengonsumsi pun dapat dipengaruhi oleh ideologi-ideologi dominan yang ada dalam sebuah masya rakat. Mengonsumsi seolah menjadi hal yang alami, namun sesungguhnya hal tersebut dipengaruhi oleh adanya ke kuasaan yang melekat dalam praktek budaya. Begitupula halnya dengan Amelia, perilaku konsumsinya tidak bisa dilepaskan dari kekuasaan ideologi yang pada akhirnya turut menentukan gaya hidupnya sebagai perempuan urban Jakarta yang konsumtif.

Dari latar belakang yang telah disampaikan diatas, muncul pertanyaan penelitian: Bagaimana tubuh perempuan urban Jakarta yang tercermin melalui sosok Amelia dalam Miss Jinjing Belanja Sampai Mati (2008) dikonstruksi dalam budaya konsumen Indonesia? 


\section{B. METODE PENELITIAN}

$\mathrm{K}$ ajian ini adalah kajian terhadap teks (buku non fiksi gaya hidup) Miss Jinjing Belanja Sampai Mati (2008) karya Amelia Masniari. Metodologi penelitian yang digunakan dalam kajian ini adalah metode kualitatif dengan pendekatan Cultural Studies. Pendekatan ini melihat bagaimana perilaku konsumsi sebagai sebuah praktek kebudayaan memiliki relasi yang kuat dengan kekuasaan. Dalam hal ini, ideologi mainstream yang muncul dalam sebuah budaya memiliki kuasa atas tubuh yang mengonsumsi. Metodologi penelitian terfokus pada pembacaan teks dan melihat isu yang muncul di dalam teks. Analisis dilakukan dengan melihat sosok Amelia di dalam teks sebagai cermin perempuan urban Jakarta melalui perilaku konsumsinya dengan menggunakan konsep tubuh dalam budaya konsumen Mike Featherstone. la adalah teoretikus konsumsi postmodern yang mengungkapkan bahwa dalam posmodernisme, manusia mengonsumsi bukan karena use value (nilai guna) tetapi karena nilai simbolik (symbolic value) yang dilihat dari nilai tukar dibalik sebuah komoditas (Soedjatmiko dalam Rosida, 2014). Konsepnya mengenai tubuh dalam budaya konsumen adalah bahwa tubuh menjadi sarana untuk mendapatkan kesenangan dan ekspresi diri (Featherstone, 1982, 1991, 2010). Dengan menggunakan konsep tubuh dalam budaya konsumen tersebut, kemudian dilihat bagaimana perilaku konsumsi Amelia dan bagaimana tubuhnya dikonstruksi oleh ideologi-ideologi dominan yang muncul dalam budaya konsumen Indonesia.

\section{HASIL DAN PEMBAHASAN}

$\mathrm{D}$ alam budaya konsumen, tubuh memegang peranan penting, karena melalui tubuhlah seseorang dapat mengkonstruksi identitasnya berdasarkan apa yang dikonsumsinya. Dalam budaya ini, tubuh diartikan sebagai tubuh yang mengonsumsi berbagai komoditas yang ditawarkan industri kapitalis, dan dalam waktu yang sama tubuh juga menjadi komoditas itu sendiri karena ia diukur dari nilai tukar atau nilai jual yang dimilikinya. Buku non fiksi Miss Jinjing Belanja Sampai Mati (2008) karya Amelia Masniari mengungkap bagaimana tubuh menjadi media yang sangat penting khususnya dalam mengartikulasikan identitas sosial dan sebagai sarana untuk mendapatkan kese nangan.

Buku ini terdiri dari 26 bab yang dipaparkan Amelia dengan begitu singkat dan menarik dengan menggunakan bahasa Indonesia dan bahasa Inggris. Melalui tulisannya Amelia menjadikan pembaca sebagai teman curhat, hal ini terlihat dari sapaan "hi..." dan paparan yang dilontar kannya pada pembaca seperti "Semasa kecil, saya punya imajinasi lebih daripada anak-anak sebaya saya......setelah menikah, saya sempat berhenti menekuini menulis, biasalah karena urusan anak dan suami yang tak ada habisnya"(hal: 2). Paparan tersebut merupakan salah satu contoh sekaligus menjadi ciri khas tulisan Amelia dalam Miss Jinjing Belanja Sampai Mati (2008) yang mencoba berbicara kepada pembaca layaknya seorang teman. Pada awal bab buku ini pun ia menulis "saya sangat menikmati setiap acara berbelanja" (hal:5) yang memperjelas identitasnya sebagai perempuan urban Jakarta yang gila belanja. Dengan menjadikan pembaca sebagai teman curhat, Amelia juga mencoba mempengaruhi pembaca khususnya perem puan Indonesia kelas menengah untuk mengonsumsi seperti dirinya.

Dalam halaman sampul, tubuh Amelia sendiri dihadirkan dan ditampilkan sebagai sosok perempuan berusia dibawah 40 tahun dengan tas-tas belanjaan di sebelah kiri dan kanan tubuhnya. la juga tampil dengan per hiasan seperti anting, cincin dan gelang warna emas yang cukup menarik perhatian. Berbelanja pada akhirnya menjadi hal yang penting untuk ditampilkan di ruang urban Indonesia.

Seiring diterbitkannya buku ini, Ameliapun mendirikan sebuah komunitas yang diberi nama Komunitas BSM (Belanja Sampai Mati) yang sebagian besar ang gotanya adalah pembaca buku ini dan perempuan-perempuan urban Indonesia 
yang memiliki hobi yang sama dengannya yaitu berbelanja. Amelia sendiri saat ini dikenal sebagai ikon BSM. Miss Jinjing Belanja Sampai Mati menjadi judul buku ini berkenaan dengan berbagai pengalaman Amelia yang mencari dan memburu belanjaan seperti baju, sepatu, tas, perhiasan dan komoditas-komoditas lain dari berbagai pelosok di Indonesia seperti jambi, bengkulu dan lain-lain hingga ke luar negeri. la seringkali berbelanja dari mulai buka hingga tutupnya pusat-pusat perbelanjaan yang mengakibatkan kelelahan pada dirinya. Rasa lelah yang mendera Amelia tersebut bukan hanya disebabkan oleh lamanya waktu yang dihabiskan untuk berbelanja tetapi juga disebabkan oleh banyaknya jinjingan belanjaan yang memenuhi tangan kiri dan kanannya. Hal tersebut menye babkan Amelia tak sanggup lagi untuk berbelanja dan pada akhirnya ia memutus kan untuk mengakhiri aktifitas belanjanya pada hari itu dan akan dilanjutkan di harihari berikutnya.

Melalui analisis teks Miss Jinjing Belanja Sampai Mati (2008), ditemukan bahwa tubuh perempuan urban Jakarta dalam budaya konsumen Indonesia yang tercermin melalui tokoh Amelia dikonstruksi oleh ideologi kapitalisme, konsumerisme dan ideologi patriarki. Ketiga ideologi ini muncul bersamaan tanpa saling meruntuhkan. Jadi, dapat dikatakan bahwa tubuh perempuan urban Jakarta (Amelia) dalam budaya konsumen Indonesia menjadi situs pertaru ngan ideologi.

Adapun argumen yang diangkat melalui pembacaan teks Miss Jinjing Belanja Sampai Mati (2008) adalah mengenai tubuh sebagai etalase status sosial, relasi komo ditas dengan tubuh, nilai patriarki dan nilai diri serta citra tubuh dan kecantikan ideal. Semua argumen tersebut didapat berdasar kan ideologi yang muncul dibalik pembacaan teks.

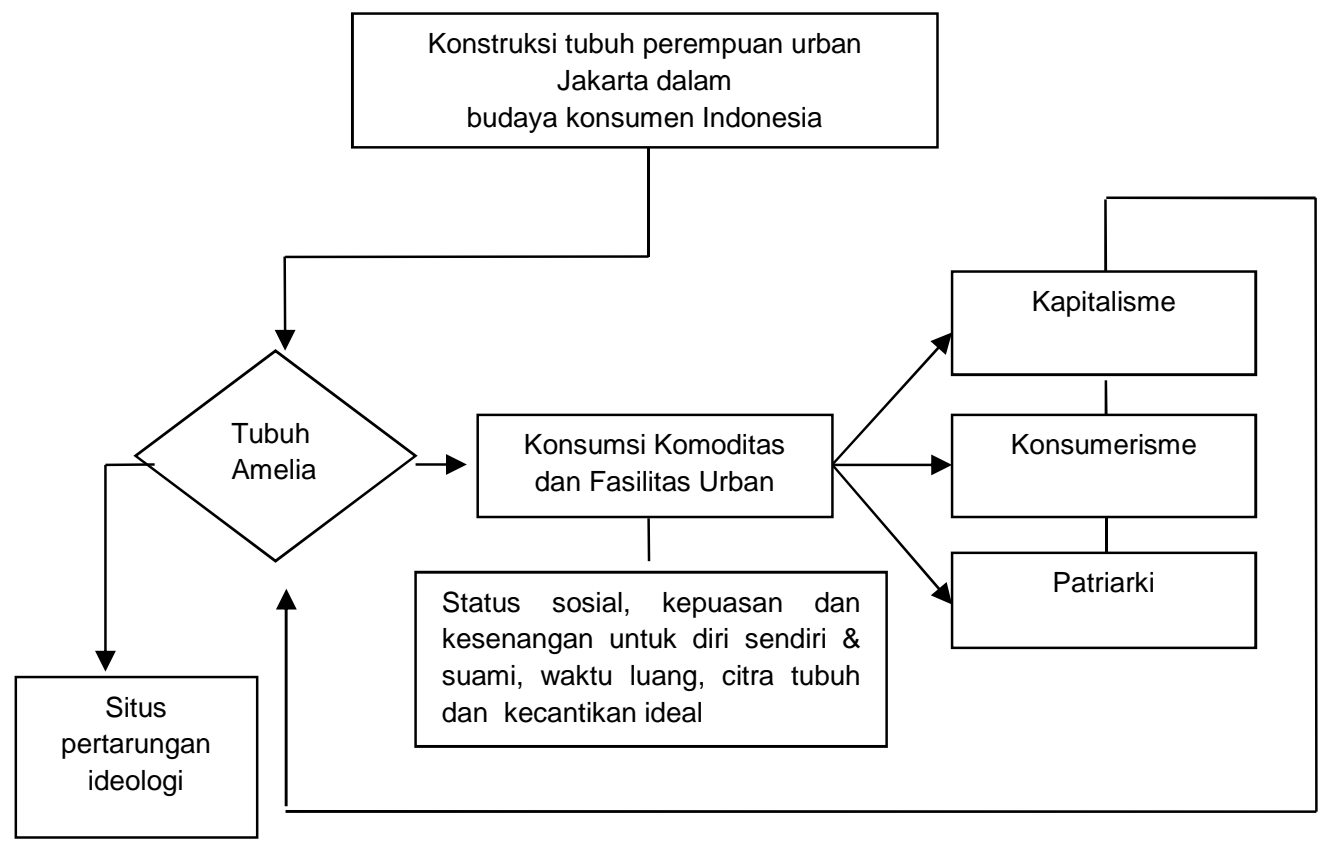

\section{Tubuh sebagai Etalase Status Sosial}

Bagi sebagian orang, status sosial yang disandangnya merupakan hal yang penting untuk ditunjukkan. Bagi orang seperti ini, konsumsi bisa jadi berfungsi sebagai media performatif dimana mereka bisa menunjukan siapa diri mereka dan berasal dari kelas mana. Maka dari itu, mengenakan produkproduk bermerk yang memiliki nilai jual tinggi dianggap hal yang tepat dalam mengomunikasikan status sosial tersebut.

DOI: 10.25077/jantro.v20.n1.p85-101.2018

JANTRO ISSN: 2355-5963 (Online)

under Lisensi Creative Commons Atribusi-BerbagiSerupa 4.0 Internasional 
Dalam Miss Jinjing Belanja Sampai Mati (2008), Amelia mengatakan bahwa hal terpenting dalam mengonsumsi produk branded adalah status sosial yang diperoleh melalui konsumsi produk tersebut. Hal tersebut disampaikan Amelia dalam sebuah bab yang berjudul "20 Items You Should Buy Before You Die" la menuturkan pengala mannya ketika bepergian dengan menenteng Louis Vuitton, produk branded asal Francis

“.......saat traveling ke luar negeri, menenteng koper LV itu gengsinya beda. Kalau nggak percaya, silahkan praktikkan sendiri. Tas LV itu membuat kita mendapat perlakuan baik dan senyuman manis dari officer, GRO, sampai bell boy"( 2008: 95).

Teks di atas memberi gambaran bahwa status sosial yang disandang seseorang sangatlah penting untuk ditunjukkan. Untuk menunjukkan kelas sosial tersebut, kon sumsi produk branded pun menjadi pilihan. Louis Vuitton adalah tas produksi Francis yang menduduki urutan Pertama high ends brand pada tahun 2004-2006 dengan harga US\$ 17,606 (Okonkwo: 2016). Dapat dibayangkan bahwa siapapun yang men jinjing tas ini pasti memiliki kemampuan finansial yang tinggi. Dalam hal ini, tas branded dengan harga ratusan juta rupiah menjadi salah satu pilihan Amelia untuk menunjukkan siapa dirinya dan berasal dari kelas mana. la memiliki keinginan untuk menunjukkan siapa dirinya dan diakui sebagai golongan kelas tertentu berda sarkan apa yang la konsumsi. Menurut Ismail (2017), beberapa orang dalam sebuah masyarakat memiliki gaya hidup tertentu dengan tujuan untuk memperlihatkan siapa dirinya, dan melihat apa persamaan dan perbedaan dirinya dengan orang lain. la mengungkapkan bahwa gaya hidup yang dipilih seseorang disebabkan oleh beberapa faktor diantara nya faktor struktural seperti status dan kelas sosial dan faktor non-struktural seperti selera (Ismail, 2017 dari Weber 1966; Veblen 1966; Bourdieu 1984; Reimer 1989). Dalam pemilihan tas yang dilakukan Amelia, selera dan kelas sosial yang melatarbe DOI: 10.25077/jantro.v20.n1.p85-101.2018

JANTRO ISSN: 2355-5963 (Online)

under Lisensi Creative Commons Atribusi-BerbagiSerupa 4.0 Internasional lakanginya memiliki pengaruh yang cukup besar terhadap gaya hidupnya sebagai perempan urban.

Tas branded yang dimiliki Amelia sebagaimana dituturkannya, membuat dirinya merasa lebih dihargai, disegani dan dihormati oleh orang lain. Hal ini disebabkan oleh adanya nilai tukar tinggi yang dimiliki tas tersebut, sehingga siapapun yang mengenakan tas ini dianggap memiliki nilai tukar yang tinggi pula. Baudrillad (dalam Haryatmoko, 2010) menuturkan, akan selalu ada perbedaan antara dihargai berdasarkan kualitas alamiah dan dihargai berdasarkan suatu model atau kode yang dibentuk. Pendapat ini menegaskan bahwa penghar gaan yang diberikan pada setiap orang akan berbeda-beda, dan dalam hal mengonsumsi tas branded, seseorang dihargai karena dikaitkan dengan model dan kode tertentu yang dimiliki tas tersebut.

Tas branded yang dipakai oleh Amelia, dijadikan alat untuk mengontruksi identitas sosial yang ingin ia tunjukkan. Tas Louis Vuitton dianggap bisa mengonstruksi iden titas sosialnya karena ia memiliki nilai tukar yang tinggi. Tubuh Amelia dalam budaya konsumen Indonesia dilihat layaknya sebuah komoditas. Tinggi rendahnya nilai tukar sebuah komoditas yang dikenakan Amelia, akan berpengaruh terhadap peni laian orang mengenai status sosial yang ia miliki. Maka dari itu, Amelia berusaha mengonstruksi tubuhnya ke dalam komo ditas tertentu untuk mendapatkan penilaian mengenai identitas sosialnya. Amelia melalui tulisannya mencoba mantasbihkan dirinya dan tubuhnya dengan gaya hidup urban yang sebaiknya diikuti oleh perem puan urban seusianya. Dengan kata lain, tubuh Amelia disini merupakan etalase sosial karena dilihat dari tampilan dan apa yang melekat pada tubuhnya.

Konsumsi Amelia terhadap produk branded memperlihatkan kerja ideologi kapi talis untuk membangun sebuah pemaknaan sosial yang melekat dalam sebuah komoditas, yaitu semakin tinggi nilai sebuah komoditas, semakin tinggi pula status sosial yang dimiliki seseorang. Hal ini terinter nalisasi dalam diri Amelia yang meyakini bahwa dengan tas branded ia akan lebih 
dihormati dan disegani karena tas tersebut memiliki nilai tukar yang sangat tinggi. Kemudian, ketika Amelia melakukan travelling dan menenteng tas LV di luar negeri, ia menjadikan negara tersebut sebagai ruang urban dimana ia bisa didilihat dan dihargai sebagaimana komoditas yang ia kenakan. Dalam budaya konsumen, ruang-ruang yang ada di kota-kota besar menjadi arena persaingan dan ajang pamer di mana setiap orang bisa melihat dan dilihat untuk dinilai sama seperti komoditaskomoditas lain yang memiliki nilai jual atau nilai tukar.

Disisi lain, ada sebuah kontradiksi antara keinginan Amelia untuk menunjukkan status sosialnya melalui konsumsi produk branded dengan keinginannya untuk bebas menjadi diri sendiri tanpa dinilai status sosialnya. Hal tersebut ditemukan pada bab Miss Jinjing and Friends yang membahas pengalaman Amelia ketika berbelanja di Singapura.

".........kita bebas jalan-jalan di mall hanya dengan mengenakan short, tank top dan sandal flip-flop, tanpa harus dilirik dengan sinis oleh orang lain dan sales attendant butik. Coba kalau di Indonesia, berpenampilan seadanya pasti malah dipandang sebelah mata, melecehkan. Pokoknya harus rapi, wangi, dan niat dandan. Beda banget........"(2008: 21)

Dalam kutipan di atas, Amelia menya takan bahwa pelayanan baik dari sales attendant di berbagai mal Indonesia akan didapatkan jika kita sebagai pembeli berpenampilan rapi, wangi, dan berdandan. Seandainya hanya mengenakan sandal flipflop dan memakai baju yang tidak rapi dan tidak dandan, maka kita akan dipandang sebelah mata dan dianggap tidak mampu membeli produk yang tersedia di pusatpusat perbelanjaan tersebut. Artinya, bahwa status sosial pun harus ditunjukkan ketika berbelanja di Indonesia. Namun, Amelia menginginkan kebebasannya sebagai diri sendiri tanpa dinilai status sosialnya, dimana ia merasa lebih bebas dan merasa lebih senang ketika berbelanja. Di Singapura, ia merasa senang karena sales attendant di pusat perbelanjaan disana tidak akan memandang rendah pengunjung yang tidak DOI: 10.25077/jantro.v20.n1.p85-101.2018

JANTRO ISSN: 2355-5963 (Online)

under Lisensi Creative Commons Atribusi-BerbagiSerupa 4.0 Internasiona dandan, tidak rapi, bahkan hanya menggunakan sandal flip-flop. Baik yang rapi atau tidak, yang dandan atau tidak, memakai high heels atau flip-flop, semua dilayani dengan sopan dan ramah sehingga Amelia-pun merasa nyaman berada didalam mall tersebut.

Dari paparan di atas, bisa dilihat bahwa ada kontradiksi dari tuturan Amelia yang menganggap bahwa status sosial itu penting untuk ditunjukkan yakni melalui konsumsi produk-produk branded. Namun, disisi lain ia menginginkan sebuah kebebasan untuk menjadi diri sendiri tanpa dipandang status sosialnya. Kontradiksi ini menunjukkan bahwa tubuh Amelia dalam budaya konsumen Indonesia sangat dipengaruhi oleh ideologi kapitalisme, sehingga ia berusaha mengonstruksi identitas sosialnya melalui konsumsi produk branded. Dengan mengenakan tas branded yang memiliki nilai tukar atau nilai jual yang tinggi, ia pun mendapatkan apresiasi dari apa yang telah dikonsumsinya yaitu pelebelan status sosial dan keinginan untuk dihargai dan dihormati sesuai dengan kelas sosialnya tersebut. Hal ini terjadi karena di Indonesia penampilan luar sangat dilihat, sehingga pengonsumsian komoditas dengan nilai tukar tinggi dapat mempengaruhi pelebelan status sosial bagi setiap orang termasuk Amelia.

Di sisi lain, ketika tubuh Amelia berada di Singapura, ia tampil sederhana dan apa adanya tanpa ingin dinilai status sosialnya. Hal ini menunjukkan bahwa ideologi kapitalisme yang muncul di Indonesia, tidak hadir dalam tubuh Amelia yang berada dalam budaya konsumen Singapura. Artinya, ideologi kapitalisme ini hanya muncul dalam budaya konsumen Indonesia sehingga Amelia tidak berusaha mengon struksi identitas sosialnya dalam budaya bangsa lain. Dalam hal ini, tindakan mengonsumsi Amelia di Singapura bebas dari ideologi kapitalisme sebagaimana ideologi ini sangat kuat terdapat dalam budaya konsumen Indonesia.

Perilaku konsumsi Amelia yang berkaitan dengan kelas sosial selain terdapat pada pengonsumsian komoditas, bisa dilihat juga melalui penulisan buku Miss Jinjing Belanja Sampai Mati (2008) yang banyak menggu nakan bahasa Inggris. Bahasa Inggris yang 
digunakan Amelia dalam memaparkan pengalamannya merupakan sebuah cara yang dipilih Amelia untuk mengonstruksi identitas kelasnya. Penggunaan bahasa Internasional dianggap mampu memperjelas identitasnya sebagai perempuan kelas menengah-atas.

\section{Relasi Komoditas dengan Tubuh}

Selain sebagai penguat status sosial, penggunaan komoditas memiliki hubungan erat dengan tubuh perempuan tepatnya melalui sebuah komoditas yang pema kaiannya tidak bisa dilepaskan dari tubuh pemakainya, sebagai contoh, sepatu, kebaya dan berlian. Ketiga komoditas ini melekat pada tubuh dan tidak dapat di tanggalkan di sembarangan tempat sebagai mana penggunaan tas.

Komoditas pertama yang memiliki relasi dengan tubuh adalah sepatu, komoditas ini memiliki kekuatan untuk mengonstruksi kecantikan perempuan, sehingga sepatu ini harus tetap melekat pada tubuh. Hal tersebut dipaparkan Amelia yang senang berburu sepatu high heels-stilleto dan dibahas pada bab Busted I'm Addicted to...(hal:99-111). la mengatakan bahwa kegemarannya terhadap sepatu high heelsstilleto adalah demi menunjang kecanti kannya dan demi menumbuhkan rasa percaya diri. la menyetujui pendapat Edward Hutabarat yang mengatakan bahwa jika perempuan memakai stilleto, postur tubuhnya jadi lebih bagus karena badan jadi lebih tegap dan dada membusung. Amelia menuturkan pengalamannya ketika menge nakan high heel nya:

"Waktu kerja jadi sales apartment, saya setiap hari kuat memakai sepatu $10 \mathrm{~cm}$, naik tangga darurat bangunan yang belum jadi. Pernah, tanpa pemberitahuan sebelumnya, di gedung Chase Plaza ada latihan pemadam kebakaran. Saya turun tangga 21 lantai pakai stilleto. Buset deh. Tapi, saya tidak kapok, tuh. justru tidak percaya diri kalau tidak pakai stilleto. Semakin tinggi, semakin berasa percaya diri banget dan seksi". (2008: 102).

DOI: 10.25077/jantro.v20.n1.p85-101.2018

JANTRO ISSN: 2355-5963 (Online)

under Lisensi Creative Commons Atribusi-BerbagiSerupa 4.0 Internasional
Dari kutipan diatas, konsumsi Amelia terhadap sepatu high heels adalah demi tercapainya rasa percaya diri yang tinggi. Walaupun sebenarnya memakai high heels tersebut membuat capek kaki, namun, demi mendapatkan rasa percaya diri dan tampil cantik, Amelia tidak pernah merasa bosan untuk mengenakan sepatu high heels tersebut. Dalam hal ini, kecantikan sangat bergantung pada konsumsi tubuh terhadap sebuah komoditas. Penggunaan high heels yang dianggap Amelia membuat dirinya tampil seksi dan cantik, menunjukkan bahwa dalam tindakan mengonsumsi tersebut, kecantikan dikonstruksi oleh tubuhnya. Dapat dikatakan bahwa tubuh cantik Amelia ia konstruksi melalui pemakaian high heels karena kecantikan tubuhnya bisa dicapai dengan menggunakan sepatu high heels tersebut. Semakin tinggi hak sepatu yang dikenakan, semakin tinggi pula rasa percaya diri yang didapatkan.

Dalam pengonsumsian terhadap high heels, Amelia mengonstruksi tubuhnya sebagai pengaruh ideologi konsumerisme yang sangat kuat dalam budaya konsumen Indonesia. Amelia mengonstruksi tubuhnya didasarkan pada ideologi konsumerisme yang menanamkan nilai-nilai kepuasan dan kesenangan diri. la dapat dengan mudah mengonstruksi kecantikan tubuhnya melalui konsumsinya terhadap komoditas yang dianggap mampu menyulap dirinya menjadi seseorang yang lebih baik dan lebih cantik.

Sepatu dikatakan berkorelasi dengan tubuh bisa terlihat dari perilaku Amelia yang memiliki kebiasaan aneh yang biasa ia lakukan setiap kali membeli sepatu. Ketika malam hari tiba, Amelia akan memakai tidur sepatunya itu hingga pagi.

"Sehabis belanja sepatu, saya punya kebiasaan yang tidak normal. Setiap punya sepatu baru, saya biasanya harus"memerawankan"sepatu itu dengan membawanya tidur semalam. Kalau baru bangun, rasanya senang sekali".(2008: 103)

Kebiasaan Amelia yang selalu memakai sepatu barunya semalaman nyatanya memberi kepuasan tersendiri bagi dirinya. la merasa sangat senang ketika membawa 
tidur sepatunya itu hingga pagi. Amelia menggunakan kata memerawankan dalam tanda kutip seolah ingin menyampaikan bahwa pleasure yang ia dapatkan dari memakai sepatu barunya semalaman sama halnya dengan sexual pleasure yang didapatkan pada malam pertama. Dalam hal ini, sepatu merupakan komoditas yang memiliki relasi dengan tubuh terutama pada kesenangan yang dirasakan tubuh itu sendiri. Sebagaimana dikatakan Feather stone (1991), bahwa dalam budaya konsumen, penampilan adalah faktor utama dalam menentukan nilai jual, karena tubuh diyakini sebagai sarana untuk menikmati kesenangan dan ekspresi diri sehingga ia mencerminkan jati diri seseorang.

"The body is proclaimed as a vehicle of pleasure and self expression. Images of the body beautiful, openly sexual and associated with hedonism, leisure and display, emphasizes the importance of appearance and the 'look'. . . . for more marketable self" that "the closer the actual body approximates to the images of youth, health, fitness and beauty the higher its exchange-value"

Inilah nyatanya yang terjadi pada Amelia. Dengan membawa tidur sepatunya itu semalaman, tubuhnya dijadikan sarana untuk mengekspresikan diri dan kesena ngan atas kecantikan yang didapatkan melalui sepatu high heels tersebut. Kecantikan itu pun tak lepas dari Ideologi. Dalam budaya konsumen Indonesia, kecantikan memiliki kriteria tertentu, seperti cantik itu putih, tinggi, langsing dan sebagainya. Ideologi ini kemudian terinternalisasi dalam diri perempuan Indonesia termasuk Amelia, sehingga ia berusaha kuat untuk mengonstruksi tubuhnya berdasarkan kriteria-kriteria cantik tersebut melalui konsumsinya terhadap komoditi seperti sepatu.

Komoditas lain yang dapat dikatakan berkorelasi dengan tubuh perempuan adalah berlian. Hal ini terlihat dari hobi Amelia yaitu mengoleksi berlian. la biasa membeli berlian bersama teman-teman perempuannya yang lain di rumah khusus penjual berlian. Kebiasaan Amelia dan teman-teman perempuannya mengoleksi berlian adalah untuk menunjang penam pilannya, karena dengan mengenakan berlian, mereka merasa lebih cantik dan seksi. Hal tersebut dibahas Amelia pada bab Bling-Bling Surprise (hal 49-91). Amelia menyampaikan pendapatnya mengenai efek pemakaian berlian terhadap dirinya

"Sekejap, setelah telinga, lengan dan leher dihias aneka berlian yang ratarata lebih dari lima karat, efeknya bikin kita merasa seperti makhluk Tuhan yang paling seksi."(2008: 53)

Bagi Amelia, berlian bisa memberi efek cantik dan seksi bagi tubuhnya. Komoditas seperti berlian dan tubuh nyatanya memiliki relasi yang kuat dalam menimbulkan rasa cantik dalam dirinya. Tindakan Amelia yang gemar mengonsumsi berlian untuk memper cantik tubuhnya, memperlihatkan bahwa tubuh dinilai dari ada tidaknya faktor-faktor yang dianggap merepresentasikan kecantikan. Ada tidaknya faktor-faktor terse but menentukan nilai jual seseorang dalam masyarakat, karena pada dasarnya seseorang senantiasa dilihat dari penampi lannya. Jadi, cantik atau tidaknya seseorang akan bergantung pada kemampuan dirinya untuk menghadirkan kecantikan tersebut yang salah satunya bisa diperoleh melalui pemakaian berlian. Sebagaimana dikatakan Jagger (2000) "anyone can be anyone-as long as they have the means to participate in consumption". Setiap orang dapat menjadi apapun seperti yang ia inginkan asalkan memiliki modal untuk membayar segala yang dikonsumsinya. Kemampuan Amelia untuk mengonsumsi berlian memberinya kemudahan untuk menjadi kannya seperti siapapun yang diinginkan termasuk menjadi makhluk Tuhan yang paling seksi. Konstruksi tubuh Amelia melalui konsumsi berlian tentu didasarkan pada ideologi cantik yang ada dalam budaya konsumen Indonesia.

Selain sepatu dan berlian, komoditas lain yang dapat dikatakan berkorelasi dengan tubuh adalah kebaya. Bagi Amelia, pakaian khususnya kebaya memiliki relasi yang kuat untuk menghadirkan kecantikan pada tubuhnya. Hal tersebut dibahas Amelia pada

DOI: 10.25077/jantro.v20.n1.p85-101.2018

JANTRO ISSN: 2355-5963 (Online)

under Lisensi Creative Commons Atribusi-BerbagiSerupa 4.0 Internasional 
bab 20 Items You Should Buy Before You Die (hal: 91-98). Amelia menyampaikan pendapatnya dalam kutipan berikut

\begin{abstract}
"perancang lain boleh datang dan pergi, tapi kebaya pengantin Edward Hutabarat akan selalu ada selama nya. Harus diakui, harga kebaya rancangannya memang benar-benar bikin kepala pusing, tapi saat dikenakan maka sama-sama setuju, dengan saya. Ada harga ada mutu. perasaan saat kain kebaya melekat dibadan, tuh, kayak puteri keraton saja-yang cantik, ayu, dan juga langsing. Bang edo bisa bikin saya yang merasa seperti itik buruk rupa ini menjadi angsa cantik yang meme sona"(2008: 91-92)
\end{abstract}

Sama halnya dengan sepatu dan berlian, kebaya yang dikenakan Amelia membuat nya merasa cantik. Melalui kebaya inilah, Amelia merasakan dirinya yang ia ibaratkan seperti itik buruk rupa menjadi perempuan cantik yang diibaratkan dengan angsa cantik yang memesona. Kebaya Edward Hutabarat dianggapnya memiliki kekuatan untuk menyulap dirinya menjadi puteri keraton yang cantik, ayu dan langsing.

Dalam tindakan mengonsumsi, segala sesuatu dimungkinkan akan terjadi. Maksud nya adalah bahwa dalam tindakan mengonsumsi, seseorang bisa menjadi siapapun yang mereka inginkan sejauh mereka telah siap untuk mengonsumsi. Tubuh pun dinilai layaknya komoditas karena ia memiliki nilai tukar atau nilai jual. Kecantikan yang ditimbulkan dari pengonsumsian kebaya di atas menunjuk kan bahwa tubuh bisa dikonstruksi melalui komoditas yang dikenakan. Nilai tubuh bergantung pada nilai komoditas yang melekat pada tubuh. Sehingga kecantikan komoditas identik dengan kecantikan tubuh. Kecantikannya bergantung pada bagaimana seseorang mengenakan nilai tukar sebuah produk untuk mengonstruksi kecantikannya. Pengonsumsian Amelia terhadap kebaya pun tak lepas dari ideologi yang muncul dalam budaya konsumen Indonesia. Kebaya merupakan pakaian tradisional masyarakat
Indonesia yang melambangkan kecantikan seorang wanita. Maka dari itu, Amelia mengonstruksi kecantikan tubuhnya melalui pemakaian kebaya buatan Edward Huta barat.

\section{Nilai Patriarki}

Merawat tubuh merupakan salah satu gaya hidup yang terbentuk dalam masya rakat perkotaan saat ini. Fasilitas-fasilitas yang terdapat diperkotaan seperti salon kecantikan, spa, klinik kecantikan dan lainlain memberi kemudahan tersendiri bagi perempuan urban Jakarta untuk melakukan perawatan tubuh apapun termasuk perawa tan tubuh yang paling sensitif. Dalam Miss Jinjing Belanja Sampai Mati (2008), Amelia mengatakan bahwa gaya hidup perempuan urban di Jakarta terutama terhadap perawa tan tubuh dan kecantikan adalah demi menyenangkan dan memuaskan suami. Hal tersebut bertujuan demi terjaganya jalinan rumah tangga yang harmonis baik lahir maupun batin, dan sebagai pencegahan supaya suami tidak berselingkuh. Melekat nya nilai-nilai patriarki dibalik perilaku konsumsi perempuan urban Jakarta yang tercermin melalui tokoh Amelia dalam Miss Jinjing Belanja Sampai Mati (2008) menunjukkan bahwa tubuh perempuan urban Jakarta dalam budaya konsumen Indonesia sangat dipengaruhi oleh ideologi patriarki yang telah lama mengakar dalam budaya Indonesia. Dalam budaya konsumen Indonesia, perempuan seolah memiliki kebebasan untuk mengonsumsi berbagai komoditas dan fasilitas yang tersedia didaerah perkotaan, namun disisi lain perempuan ini diikat ideologi ibuisme yang menekankan kodrat perempuan sebagai istri dan ibu termasuk dalam hal memuaskan suami secara seksual. Nilai patriarki tersebut dibahas Amelia dalam bab tersendiri pada halaman 151-161 dengan judul "Things To Do To Satisfied Your Husband" (sic).

Berikut kutipan Amelia mengenai perawatan tubuh yang ia lakukan demi suaminya:

"dimulailah penotokan vagina. Dipijat hanya dengan pencetan ujung jari

DOI: 10.25077/jantro.v20.n1.p85-101.2018

JANTRO ISSN: 2355-5963 (Online)

under Lisensi Creative Commons Atribusi-BerbagiSerupa 4.0 Internasional 
namun, gila bener rasanya. Titik-titik yang ada di atas, bawah selangkangan, paha atas, lutut, betis titik-titik di kaki. Tampaknya, semua otot-otot itu saling berhubungan. Mmmppphhh, enak juga.......( 2008: 157)

Kutipan diatas menjelaskan perasaan senang yang dirasakan Amelia ketika menikmati pijatan pada area sensitifnya. Sekalipun ia melakukan treatment tersebut untuk memuaskan suaminya secara seksual, namun disisi lain ia pun menikmati treatment tersebut dan merasa puas.

Dalam budaya konsumen Indonesia, konsumsi perempuan urban Jakarta terhadap perawatan vagina sebagaimana dituturkan Amelia dipengaruhi oleh ideologi patriarki dan ideologi konsumerisme. Tubuh Amelia dikonstruksi melalui pengonsumsian perawatan tubuh karena tubuh Amelia tersebut dimaknai sebagai tubuh sosial yang tumbuh dalam budaya patriarki di Indonesia. Pada akhirnya Ideologi ini dijadikan acuan dalam segala hal termasuk dalam mengon sumsi komoditas tertentu. Ideologi yang berakar pada ideologi ibuisme ini dipopulerkan oleh negara pada masa Orde Baru. Ideologi tersebut menekankan kodrat sebagai unsur utama dalam mengatur perilaku perempuan, terutama pada peran ganda perempuan sebagai istri dan ibu termasuk didalamnya memuaskan suami secara seksual (Mochtar, 2010). Mengutip pendapat Kate Millet yang dibaca dari disertasi Diana Teresa Pakasi (2006), ia mengatakan bahwa seks itu bersifat politis karena senantiasa berlandaskan paradigma hubungan kekuasaan yang dilegitimasi oleh ideologi patriarki. Pendapat Millet tersebut memberi pemahaman bahwa dalam hal seksualitas, ideologi patriarki tidak bisa dilepaskan daripadanya. Maka dari itu, keinginan Amelia untuk memuaskan suami nya secara seksual melalui perawatan vagina yang dilakukannya, merupakan sebuah kerja ideologi budaya patriarki yang telah tertanam dalam kehidupannya. Bisa dikatakan bahwa Amelia berusaha mengonstruksi tubuhnya untuk menjadi istri ideal sesuai dengan budaya patriarki melalui perawatan bagian tubuhnya.
Selain ideologi patriarki, ideologi konsumerisme juga muncul dibalik perilaku konsumsi perempuan urban Jakarta terhadap perawatan. Hal ini bisa dilihat melalui kesenangan dan kepuasan yang dirasakan Amelia setelah mengonsumsi perawatan tubuh tersebut. Konsumerisme sendiri merupakan suatu pola pikir dan tindakan dimana orang mengonsumsi bukan karena kebutuhan, melainkan karena dengan tindakan mengonsumsi itu membe rikan kepuasan padanya. Sebagaimana dikatakan Soedjatmiko (2008), ketika orang membeli sesesuatu yang sebenarnya tidak dibutuhkan, hal ini disebutnya sebagai akar dari konsumerisme dimana anggota masya rakat tak henti mengonsumsi.

Kontradiksi antara nilai-nilai patriarki dengan kesenangan diri yang rasakan Amelia menunjukkan bahwa ada pertaru ngan dua ideologi yakni ideologi patriarki dan ideologi konsumerisme. Kedua ideologi ini memiliki pengaruh yang sangat kuat dimana perempuan urban Jakarta mengon struksi tubuhnya berdasarkan ideologiideologi yang muncul dalam budaya konsumen Indonesia. Baik ideologi patriarki maupun ideologi konsumerisme, keduanya berdampingan satu sama lain tanpa saling meruntuhkan. Hal ini bisa terlihat dalam teks dimana Amelia tetap melakukan perawatan tubuh demi kepuasan seksual suami tetapi disisi lain ia juga merasakan kesenangan dari perawatan tubuh tersebut.

\section{Nilai Diri}

Amelia adalah penggemar berat kopi. Kafe pun menjadi tempat favorit baginya untuk menikmati secangkir kopi dan cemilan lain yang tersedia. Menurut Amelia, neneknya pernah berkata bahwa perempuan harus memiliki me time yang berguna untuk introspeksi diri, cari inspirasi, pergaulan, relaksasi dan lain-lain. Bagi Amelia sendiri, me time nya adalah duduk di kafe sambil ngopi. Hal ini dibahas Amelia pada bab Busted I'm Addicted to...(Hal: 99-111). Amelia menuturkannya dalam kalimat berikut:

"dan, buat saya sekarang, me time adalah duduk di kafe sambil ngopi dan makan sesuatu....., saya punya sahabat, Omar, pakar investasi....kita 
berdua selalu menyediakan waktu khusus untuk ngopi dan makan cake yang enak, atau sekedar nyobain kafe baru.Biasanya, tidak terasa, kita bisa menghabiskan waktu berbincangbincang dari yang curhat pribadi, non sense, sampai masalah serius negara ini. Kami pernah janjian di Singapura, makan bebek peking kesukaan kami berdua, lalu ngopi sampai malam. Serasa surga". (2008:110-111)

Ngopi dan makan di kafe bisa dikatakan sebagai gaya hidup masyarakat perkotaan saat ini. Hal ini didukung dengan adanya waktu luang yang bisa mereka gunakan untuk menyenangkan diri baik dilakukan sendiri, bersama teman-teman atau bersa ma keluarga. Me time yang dikatakan Amelia adalah kebebasan yang ia punya untuk menyenangkan dirinya sendiri dengan menikmati hidangan kopi dan cake yang nikmat. Amelia memiliki kebebasan dalam menggunakan waktu luangnya sesuai dengan keiinginannya. Selain kesenangan yang ia dapat dari mengonsumsi secangkir kopi di kafe, ia pun bisa bertukar pikiran dan bersosialisasi dengan teman yang ia ajak untuk nongkrong di kafe tersebut. Bisa dikatakan bahwa kafe yang dikunjungi Amelia dijadikan salah satu tempat penting di mana ia bisa bersosialisasi, bersantai bersama teman-teman, atau sekedar menghabiskan waktu. Dapat dikatakan pula bahwa keberadaaan fasilitas-fasilitas diper kotaan seperti kafe ini, menawarkan kebebasan bagi perempuan urban Jakarta seperti Amelia untuk menciptakan ruang sosialnya di luar rumah sehingga ia bisa bebas melakukan berbagai kesenangan yang diinginkan. la bisa bersantai dan bersosialisasi untuk kepuasan dan kesenangan dirinya.

Dalam hal ini, konstruksi tubuh Amelia didasarkan pada budaya waktu luang yang diciptakan industri kapitalis. Kafe dijadikan industri untuk menarik masyarakat kedalam ranah konsumsi yang berbeda. Kafe tidak hanya dijadikan sebagai tempat untuk minum kopi saja, tetapi sengaja diciptakan untuk memfasilitasi kebutuhan seseorang untuk bersosialisasi dengan sahabat, rekan kerja atau keluarga. Amelia mengonsumsi DOI: 10.25077/jantro.v20.n1.p85-101.2018

JANTRO ISSN: 2355-5963 (Online)

under Lisensi Creative Commons Atribusi-BerbagiSerupa 4.0 Internasional gaya hidup tersebut karena ia memiliki kemampuan finansial yang mendukung sehingga adanya fasilitas-fasilitas perkotaan seperti cafe menunjang kebutuhan Amelia untuk mendapatkan kesenangan pada dirinya. Dapat disampaikan bahwa Amelia telah menjadikan tubuhnya sebagai sarana untuk menikmati kesenangan dengan menghabiskan waktu luang yang dimilikinya di sebuah ruang urban yaitu kafe.

\section{Citra Tubuh dan Kecantikan Ideal}

Citra tubuh dan kecantikan ideal merupakan hal yang diidamkan banyak perempuan. Tidak sedikit dari mereka yang berusaha sekeras mungkin untuk menam pilkan tubuh ideal yang sesuai dengan kriteria-kriteria cantik seperti putih, tinggi, langsing dan seterusnya, yang pada akhirnya berpengaruh pada perilaku konsumsi mereka. Hal tersebut didukung pula oleh industri kecantikan yang terusmenerus memproduksi dan menawarkan produk-produk kecantikan yang dianggap bisa mewujudkan tubuh ideal tersebut.

Dalam Miss Jinjing Belanja Sampai Mati (2008) tepatnya pada bab Size Doesn't and Does Matter (hal: 37-48), Amelia memaparkan usahanya untuk mendapatkan berat tubuh yang ideal yang dapat menunjang kecantikannya. Bagi Amelia, kegemukan badan membuatnya frustasi dan tidak percaya diri. Baginya keinginannya untuk mengubah penampilan (gemuk menjadi langsing) adalah segalanya. Hal ini terkait dengan adanya interview dan sesi pemotretan disebuah majalah (Chic). Amelia ingin tampil cantik dengan badan yang langsing dalam interview dan sesi pemotretan tersebut. la-pun rela melakukan akupuntur walaupun sebenarnya ia takut dengan jarum, baik jarum suntik, jarum akupuntur atau jarum infus. Amelia menceritakan terapinya yang dibantu oleh Shinse Oleng disebuah Klinik Akupuntur

"kata shinse Oleng, si pembuluh darah kita, tuh, ada banyak sekali lemak, terutama orang yang obesitas seperti saya. Jadi, proses pemanasan itu dilakukan agar lemak-lemak luruh, peredaran darah jadi lancar......Ko 
Oleng bilang saya harus datang dua kali seminggu....nah, pas mau pulang, ada pesan dari Ko Oleng, kalau mau lebih cepet kurus, harus ngurangin makan dan rajin olahraga". (2008: 4445)

Amelia menganggap tubuh yang langsing adalah tubuh yang cantik dan diidamkan. Tubuh yang cantik adalah tubuh yang langsing. Perempuan senantiasa berusaha untuk menghilangkan lemak pada tubuh karena lemak tersebut dapat mengurangi kecantikan seorang perempuan. Timbunan lemak dalam tubuh dianggap sebagai sesuatu yang buruk dan berdampak pada turunnya nilai seseorang karena tubuhnya yang tidak cantik. Haskins dan Ransford (1999) mengatakan bahwa berat badan berpengaruh pada karir dan penghasilan perempuan. Hal ini berlaku bagi Amelia yang menginginkan tubuh langsing dan ideal untuk menunjang karirnya sebagai penulis terkenal. Hal tersebut juga menunjukkan bahwa tubuh yang ideal adalah tubuh yang dihargai dan bernilai lebih tinggi, sehingga kebanyakan perempuan melakukan segala usaha untuk melangsingkan tubuhnya. Menurut Wolf (1990) yang dibaca dari Sarah Gamble (2004), ia mengatakan "obsesi terhadap kecantikan dan ketidakpuasan terhadap diri sendiri karena tidak sesuai dengan tuntutan yang dicitrakan mengaki batkan perempuan melukai tubuh mereka dengan operasi plastik dan gangguan pola makan". Hal ini berlaku bagi Amelia yang merasakan ketidakpuasan atas tubuhnya yang gemuk, sehingga ia mau melakukan terapi tusuk jarum yang menyakitkan demi tercapainya citra cantik bagi tubuhnya. Dengan tubuh yang langsing, kepuasan terhadap diri sendiri muncul sebagaimana dikatakan Bordo (1989) "thinner women may be perceived as both feminine and having power and control over their bodies". Setelah mendapat kepuasan dengan memiliki tubuh langsing, kesenangan diri pun akan muncul, dengan mengutip kembali pendapat Featherstone (1991), ia menga takan bahwa tubuh dianggap sebagai sarana kesenangan dan ekspresi diri

"The body is proclaimed as a vehicle of pleasure and self expression.
Images of the body beautiful, openly sexual and associated with hedonism, leisure and display, emphasizes the importance of appearance and the 'look'. . . . for more marketable self" that "the closer the actual body approximates to the images of youth, health, fitness and beauty the higher its exchange-value"

Usaha untuk melangsingkan tubuh yang dilakukan Amelia menandakan bahwa tubuh tersebut menjadi sarana kesenangan dan ekspresi dirinya. Citra tubuh yang cantik bisa didapatkan melalui tindakan konsumsi yang dalam hal ini, terapi akupuntur dipilih Amelia untuk mengonstruksi kecantikan tubuhnya.

Konstruksi tubuh Amelia ini tentu dipengaruhi oleh ideologi kapitalisme yang menciptakan berbagai macam produkproduk kecantikan untuk menghilangkan kekurangan seseorang dan menciptakan tubuh yang ideal. Dalam budaya konsumen Indonesia, pengonsumsian sering kali dikaitkan dengan keberhasilan seseorang untuk tampil cantik. Ideologi ini menyusup dalam pikiran Amelia sehingga ia meyakini bahwa tubuh yang gemuk bukanlah tubuh yang cantik dan pada akhirnya ia berusaha mengubah dirinya menjadi langsing. inilah cara kerja kapitalisme yang terus-menerus menekankan pada ketidakpuasan pada tubuh yang telah dimiliki seseorang. Featherstone (2010) memaparkan lebih jauh "The vast range of dietary, slimming, exercise, and cosmetic body maintenance product wich are currently produced, marketed and sold print to the significance of appearance and bodily presentation within late capitalist society". Pemaparan tersebut memperjelas bahwa dalam masyarakat kapitalis, penampilan tubuh menempati posisi utama dalam kehidupan sehari-hari mereka. Jelas, bahwa ideology kapitalisme berperan aktif terhadap citra tubuh yang idamkan.

Selain menuturkan pengalamannya melakukan terapi akupuntur untuk melang singkan tubuh, Amelia-pun menuliskan ukuran badannya sebelum dan sesudah terapi tersebut dilakukan. Berikut adalah catatan Amelia: 


\author{
"Lingkar panggul=105 (dulu paling \\ gendut Cuma 90) \\ Lingkar pinggang= 90 \\ Lingkar dada=101 (it was 95) \\ Lingkar paha atas $=70$ \\ Lingkar ketiak ke atas bahu= 48 \\ (pantes saja pakai baju tidak pernah \\ nyaman)" (2008: 46). \\ Hasil setelah terapi satu bulan \\ “Lingkar panggul=101 ( - 4) \\ Lingkar pinggang $=86(-4)$ \\ Lingkar dada $=99(-2)$ \\ Lingkar paha atas $=67(-3)$ \\ Lingkar ketiak ke atas bahu $=46(-2)$ " \\ (2008: 47)
}

Dengan menuliskan ukuran badan sebelum dan setelah terapi, hal ini menunjukkan bahwa Amelia menginginkan pengakuan akan citra cantik tubuhnya karena ia telah berusaha keras untuk mendapatkan tubuh ideal dan kriteria cantik melalui terapi akupuntur tersebut. Dengan demikian, dapat dikatakan bahwa tubuh langsing Amelia ini sangat penting untuk ditampilkan di ruang urban. Setelah melakukan terapi dan mendapatkan tubuh langsing, Amelia kembali mendapatkan kepercayaan diri dan merasa cantik. Amelia menuturkan kegembiraannya yang berhasil menurunkan berat badan setelah terapi selama satu bulan sebagai berikut:

\begin{abstract}
"Wow, saya kaget. OMG, ada juga hasil perjuangan saya....pada awalnya saya buat ini untuk dilihat orang, tapi sekarang saya merasa melakukannya untuk menghargai hidup saya sendiri. I love me and myself...big thanks to Ko Oleng for boosting my confidence." (2008: 4748)
\end{abstract}

Kutipan di atas memperjelas bahwa tubuh cantik yang berusaha didapatakan Amelia hanya bertujuan untuk mendapatkan pengakuan cantik dari orang lain. Bisa dikatakan bahwa tubuh cantik seorang perempuan bergantung pada ukuran ideal berat tubuhnya. Citra tubuh dan kecan tikan ideal tidak hanya dapat ditampilkan melalui berat badan saja, melainkan pada wajah. DOI: 10.25077/jantro.v20.n1.p85-101.2018

JANTRO ISSN: 2355-5963 (Online)

under Lisensi Creative Commons Atribusi-BerbagiSerupa 4.0 Internasional
Wajah cantik adalah wajah tanpa keriput. Dalam hal ini, keriput pada wajah menjadi sesuatu yang menakutkan bagi sebagaian perempuan termasuk Amelia. la menga takan bahwa nasib perempuan tidaklah seberuntung laki-laki khususnya dalam hal ketampanan dan kecantikan wajah. Menurut Amelia, ketampanan laki-laki tak lekang oleh waktu, makin tua justru makin menarik, sangat jauh berbeda dengan perempuan yang kecantikannya akan pudar seiring bertambahnya usia. la tuturkan penda patnya sebagai berikut

“.......... perempuan sepertinya dimusuhin banget sama waktu. Kerutan seperti momok menakutkan yang membuat kita, perempuanperempuan malang ini, berjuang ekstra keras untuk mempertahankan kecantikan sebisa mungkin. Kalau benar-benar mau melihat sendiri sampel perempuan-perempuan takut tua ini, cari saja yang sekarang menginjak usia tiga puluh plusplus".(2008: 151)

Melalui kutipan di atas, dapat dipahami bahwa citra cantik yang melekat pada diri seorang perempuan sangatlah penting. Usaha apapun dilakukan demi tercapainya keinginan untuk tetap tampil cantik. Usaha keras yang dikatakan Amelia diatas terkait dengan konsumsi pemakain produk-produk kecantikan yang dianggap bisa mengurangi bahkan menghilangkan tanda-tanda penua an pada wajah, atau melakukan treatmenttreatment kecantikan di salon-salon, spa, atau klinik kecantikan tertentu. Semua hal tersebut dilakukan sebagai cara perempuan untuk mengekspresikan dirinya melalui kecantikan wajah, karena pada dasarnya dalam budaya konsumen, penampilan tubuh terutama wajah merupakan unsur terpenting dalam penggambaran diri seseorang.

Menurut Thompson and Hirschman (1995), citra tubuh didasarkan atas ideologi budaya yang meletakkan kepuasaan terhadap tubuh, yakni tubuh yang diimpikan (ideal). Dan, usaha-usaha yang dilakukan seseorang untuk mendapatkan tubuh yang ideal tersebut dimotivasi oleh sebuah ideologi. Dalam hal kecantikan ideal ini, 
ideologi yang berperan adalah ideologi kapitalisme dimana industri memproduksi beragam kosmetik dan produk-produk kecantikan tanpa henti sehingga memun culkan sebuah wacana yang terus menerus dibangun mengenai tubuh yang diidamkan, direpresntasikan, dan dikomo ditikan (Meliono, 2004). Pada akhirnya, Ideologi ini menyusup pikiran dan terinter nalisasi dalam diri perempuan, sehingga perempuan terus mengonsumsi produk-produk yang dianggap mampu mengonstruksi kecantikan tubuhnya. Melalui konsumsi produk-produk kecantikan terse butlah, keinginan untuk mendapatkan kecantikan ideal bisa didapatkan. Dalam hal ini, Amelia-pun terpengaruh ideologi kapitalis yang terinternalisasi dalam dirinya sehingga terus mengonsumsi komoditas yang dianggapnya mampu menghadirkan kecantikan dalam dirinya.

Dari analisis di atas, dapat disampaikan bahwa tubuh adalah proyeksi yang paling utama dalam mendukung status sosial perempuan urban Jakarta dan dapat dipastikan bahwa hal tersebut bukan terletak pada penampilan sebuah komoditas tetapi pada nilai orisinalitas komoditas tersebut. Selain itu, tubuh perempuan merupakan tempat persemaian nilai-nilai patriarki yang mengatur kehidupan perempuan urban Jakarta terutama yang telah menikah. Hal ini terkait dengan ideologi ibuisme yang menekankan kodrat perempuan sebagai ibu dan istri yang didalamnya termasuk aturan untuk melayani dan memuaskan suami secara seksual.Hal lain yang dapat disampaikan dari analisis di atas adalah bahwa tubuh adalah sarana yang paling tepat yang digunakan perempuan urban Jakarta untuk mendapatkan kepuasan dan kesenangan terhadap diri, dan dapat dipastikan bahwa hal tersebut terkait erat dengan citra cantik dan tubuh ideal yang dimiliki seorang perempuan.

Selanjutnya, konstruksi tubuh perempuan urban Jakarta dalam budaya konsumen Indonesia dalam Miss Jinjing Belanja Sampai Mati (2008) karya Amelia Masniari dapat dilihat dari nilai kapitalisme yang dapat mengonstruksi kecantikan tubuh perempuan, nilai konsumerisme yang dapat mengukuhkan identitas sosial juga nilai patriarki yang tetap mengatur kehidupan perempuan urban Jakarta. Analisis teks menunjukkan bahwa tubuh perempuan urban Jakarta yang tercermin melalui tokoh Amelia dalam budaya konsumen Indonesia dikonstruksi oleh ideologi kapitalisme, konsumerisme dan ideologi patriarki. Munculnya ketiga ideologi ini terlihat melalui kontradiksi-kontradiksi dalam teks seperti kontradiksi antara nilai-nilai kesenangan diri, status sosial juga nilai-nilai patriarki. Dalam hal ini, tubuh Amelia dikonstruksi ke dalam komoditas sebagai akibat munculnya ideo logi dominan dalam budaya konsumen Indonesia.

\section{KESIMPULAN}

$\mathrm{D}$ ari penjelasan di atas, dapat disimpulkan bahwa tubuh perempuan urban Jakarta (Amelia) dalam budaya konsumen Indonesia seperti tercermin dalam Miss Jinjing Belanja Sampai Mati (2008) merupakan situs pertarungan ideologi, yaitu ideologi kapitalisme, konsu merisme dan ideologi patriarki. Ketiga ideologi ini saling mengukuhkan satu sama lain dan tidak ada satu ideologi pun yang runtuh, sehingga pada akhirnya terjadi koherensi antar masing-masing ideologi. Implikasi praktis dari penelitian ini adalah perempuan urban dapat menjadi lebih kritis terhadap kekuasaan (ideologi-idelogi) yang mengungkung tubuhnya melalui praktek konsumsi. Mereka tidak perlu mengonstruksi tubuh sesuai tuntutan kapitalis. Menjadi diri sendiri dan berpuas diri dengan tubuh yang dimiliki. Penelitian ini tidak berhenti pada analisis teks saja, tetapi masih banyak hal yang bisa diteliti. Amelia Masniari memiliki komunitas yang ia beri nama Komunitas BSM (Belanja Sampai Mati) yang anggotanya $90 \%$ perempuan urban dari seluruh Indonesia $(60 \%$ asal Jakarta). Keterlibatan peneliti secara langsung mengamati dan mengikuti perilaku konsumsi perempuan urban Jakarta yang tergabung dalam komunitas tersebut sangat penting untuk memberikan gambaran yang lebih utuh dan jelas mengenai fenomena budaya perempuan urban Jakarta dalam budaya konsumen Indonesia.

DOI: 10.25077/jantro.v20.n1.p85-101.2018

JANTRO ISSN: 2355-5963 (Online)

under Lisensi Creative Commons Atribusi-BerbagiSerupa 4.0 Internasional 


\section{E. UCAPAN TERIMAKASIH}

$\mathrm{P}$

enulis berterima kasih kepada pihak redaksi Jurnal Antropologi: Isu-Isu Sosial Budaya, Universitas
Andalas, atas perkenannya mempublika sikan artikel ini.

\section{Daftar Pustaka}

Arnould, E. J., \& Thompson, C. J. (2005). Consumer culture theory (CCT): Twenty years of research. Journal of consumer research, 31(4), 868-882.

Bordo, Susan. 2003. Unbearable weight: feminism, Western culture, and the body. 10th Anniversary Edition. California: University of California Press.

Featherstone, M. (1982). The body in consumer culture. Theory, culture \& society, 1(2), 1833.

Featherstone, M. (2010). Body, image and affect in consumer culture. Body \& Society, 16(1), 193-221.

Featherstone, Mike. (1991). The Body in Consumer Culture. London: Sage.

Gamble, Sarah. (2004). The Routledge Companion to Feminism and Posfeminism. (Tim Penerjemah Jalasutra, penerjemah.). Yogyakarta: Jalasutra.

Haryatmoko, J. (2010). Dominasi penuh muslihat: akar kekerasan dan diskriminasi. PT Gramedia Pustaka Utama.

Haskins, K. M., \& Ransford, H. E. (1999, June). The relationship between weight and career payoffs among women. In Sociological Forum (Vol. 14, No. 2, pp. 295-318). Kluwer Academic Publishers-Plenum Publishers.

Ismail, R. (2017). Musik Rock Alternatif Dalam Kalangan Remaja: Isu Sub-Budaya Remaja Dan Pembangunan Insan Dalam Era Globalisasi. Jurnal Antropologi: Isu-Isu Sosial Budaya, 19(1), 11-25. doi:https://doi.org/10.25077/jantro.v19.n1.p11-25.2017

Jagger, Elizabeth. 2000. "Consumer bodies" dalam The body, culture and society: an introduction. Buckingham, Philadelphia: Open University Press.

Lury, C. (1996). Consumer culture. Rutgers University Press.

Masniari, Amelia (2011). Komunitas Belanja Sampai Mati, http://belanja-sampaimati.blogspot.com/2011/10/komunitas-miss-jinjing.html, diakses tanggal 30 April 2018).

Masniari, Amelia. (2008). Miss Jinjing Belanja Sampai Mati. Jakarta: Gagas Media.

Meliono, I. Budianto. 2004. Ideologi Budaya. Jakarta: Kota Kita.

Mochtar, J. (2008). Membaca ideologi jender dalam chick lit Inggris dan Indonesia (Doctoral dissertation, Universitas Indonesia. Fakultas Pengetahuan Budaya).

Noerhadi, Toeti Heraty. (2014). Aku Dalam Budaya; Telaah Metodologi Filsafat Budaya. Jakarta: Gramedia Pustaka Utama.

Okonkwo, U. (2016). Luxury fashion branding: trends, tactics, techniques. Springer.

Pakasi, D. T. (2006). Teks dan pembaca; konstruksi tubuh, hasrat, dan relasi seksual perempuan dalam fitur majalah popular (Doctoral dissertation, FPascasarjana-UI).

Rosida, I. (2014). Hasrat komoditas di ruang urban Jakarta: sebuah kajian budaya. Buletin Al-Turas, 20(1), 57-66.

Shilling, Christ. (2016). The Body: A very short introduction. Oxford university press.

Soedjatmiko, Haryanto. (2008). Saya Berbelanja, Maka Saya Ada: Ketika Konsumsi dan Design Menjadi Gaya Hidup Konsumeris. Yogyakarta: Jalasutra.

Supangkat, S. H., \& dkk. (2015). Pengenalan dan Pengambangan Smart City. Bandung: eIndonesia Initiative dan Institut Teknologi Bandung(ITB).

Synnott, Anthony. 2003. Tubuh sosial: simbolisme, diri, dan masyrakat. Yoyakarta: Jalasutra.

DOI: 10.25077/jantro.v20.n1.p85-101.2018

JANTRO ISSN: 2355-5963 (Online)

under Lisensi Creative Commons Atribusi-BerbagiSerupa 4.0 Internasional

$100 \mid \mathrm{P}$ a g e 
JURNAL ANTROPOLOGI: Isu-Isu Sosial Budaya. Juni 2018, Vol. 20 (1): 85-101

ISSN 1410-8356

Online at http://jurnalantropologi.fisip.unand.ac.id/index.php/jantro

Thompson, C.J. \& Hirschman,E. C. (1995). Understanding the Socilized Body: A Postructuralist Analysis of Consumers Self-Conception, Body Images, and Self-Care practises. Journal of Consumer Research,22, 139-153.

DOI: 10.25077/jantro.v20.n1.p85-101.2018

JANTRO ISSN: 2355-5963 (Online)

under Lisensi Creative Commons Atribusi-BerbagiSerupa 4.0 Internasional 